\title{
Modelling aspects of oviduct fluid formation in vitro
}

\author{
Constantine A Simintiras ${ }^{1}$, Thomas Fröhlich², Thozhukat Sathyapalan³, Georg J Arnold², \\ Susanne E Ulbrich ${ }^{4}$, Henry J Leese ${ }^{1}$ and Roger G Sturmey ${ }^{1}$ \\ ${ }^{1}$ Centre for Cardiovascular and Metabolic Research (CCMR), The Hull York Medical School (HYMS), Kingston upon \\ Hull, UK, ${ }^{2}$ Ludwig-Maximilian University of Munich, Munich, Bavaria, Germany, ${ }^{3}$ The Michael White Centre for \\ Diabetes and Endocrinology, Hull Royal Infirmary (HRI), Hull York Medical School (HYMS), Kingston upon Hull, \\ UK and ${ }^{4}$ Swiss Federal Institute of Technology Zurich (ETHZ), Zürich, Switzerland \\ Correspondence should be addressed to C A Simintiras; Email: hycs3@hyms.ac.uk
}

\begin{abstract}
Oviduct fluid is the microenvironment that supports early reproductive processes including fertilisation, embryo cleavage and genome activation. However, the composition and regulation of this critical environment remain rather poorly defined. This study uses an in vitro preparation of the bovine oviduct epithelium to investigate the formation and composition of in vitro-derived oviduct fluid (ivDOF) within a controlled environment. We confirm the presence of oviduct-specific glycoprotein 1 in ivDOF and show that the amino acid and carbohydrate content resembles that of previously reported in vivo data. In parallel, using a different culture system, a panel of oviduct epithelial solute carrier genes and the corresponding flux of amino acids within ivDOF in response to steroid hormones were investigated. We next incorporated fibroblasts directly beneath the epithelium. This dual culture arrangement represents more faithfully the in vivo environment and impacts on ivDOF composition. Lastly, physiological and pathophysiological endocrine states were modelled and their impact on the in vitro oviduct preparation was evaluated. These experiments help clarify the dynamic function of the oviduct in vitro and suggest a number of future research avenues, such as investigating epithelial-fibroblast interactions, probing the molecular aetiologies of subfertility and optimising embryo culture media.
\end{abstract}

Reproduction (2017) 153 23-33

\section{Introduction}

The lumen of the mammalian oviduct can be considered an optimal environment for reproductive processes including fertilisation and early embryo development (Coy et al. 2012). During this time, critical developmental events occur, including activation of the embryonic genome and fate-decisions of the blastomeres (González et al. 2011). In the bovine, the early embryo spends approximately 4 days in the oviduct before moving into the uterus (Hackett et al. 1993). Insights into the dynamic composition, formation and regulation of oviduct fluid are therefore crucial to our understanding of the early events of mammalian reproduction.

Until now, descriptions of the composition of oviduct fluid have been based on analyses from samples isolated from various species using in situ and ex vivo techniques (Aguilar \& Reyley 2005). These have included oviduct flushes from anaesthetised or slaughtered animals. As discussed by Leese and coworkers (2008), these methods are limited and offer narrow scope for experimental exploration. Thus, there is a need for a robust method of studying oviduct fluid within a controlled laboratory environment.

A single layer of epithelial cells provides the limiting barrier between the maternal circulation and the oviduct lumen. To examine oviduct fluid formation in detail, it is therefore necessary to isolate the oviduct epithelial cells and culture them in a system that maintains their proper spatial relationship as a polarised confluent layer. One method to achieve this is using the Transwell system, which enables the culture of oviduct epithelia in chambers that allow access to the apical and basal compartments (Walter 1995). This system allows the bidirectional movement of compounds across the oviduct epithelium to be examined. Using such as system, Dickens and coworkers (1993) and Cox and Leese (1995) reported that a chloride secreting epithelium sensitive to purinergic agents lined rabbit and bovine oviducts. These findings have been followed up in detail by Keating and Quinlan (2008, 2012). Moreover, the culture of bovine oviduct epithelia on Transwell inserts has allowed the basal to apical, and reverse, movement of nutrients across the oviduct epithelium to be examined (Simintiras et al. 2012).

Building on these early studies, Levanon and coworkers (2010) demonstrated that oviduct epithelia could be cultured at an apical-basal air-liquid interface in which the apical chamber was comprised of moist air. Under air-liquid interface conditions, oviduct epithelia resemble the in vivo state more closely and 
can be cultured in this manner long term (Gualtieri et al. 2012). Interestingly, patches of oviduct epithelial cells maintained at an air-liquid interface for over two weeks after confluence regained ciliation (Gualtieri et al. 2013), despite a lack of oestradiol supplementation, which is normally required for re-ciliation in vitro (Comer et al. 1998, Ulbrich et al. 2003). Chen and coworkers (2013a) cultured porcine oviduct epithelial cells for more than 10 days at an air-liquid interface together with steroid hormones and found they were morphologically closer to in vivo controls. This interesting approach results in a system in which in vitro oviduct epithelial cell cultures mimic in vivo behaviour more closely.

In spite of these advances, there is only partial knowledge of the mechanisms underlying the formation and regulation of oviduct fluid, especially when compared with epithelia lining tissues such as the gut and the airways. This can be attributed to (a) ethical and technical limitations surrounding the study of oviduct fluid in vivo and (b) the lack of a robust in vitro model enabling the exploration of the formation of oviduct fluid, and how the process responds to stimuli under controlled experimental conditions.

We now present a preparation of bovine oviduct epithelial monolayer to perform real-time experiments on oviduct-derived fluid formation in vitro. With this system, we have confirmed the secretion of OVGP1 protein into the luminal compartment, which comprises a mixture of amino acids whose composition differs from that in the basal compartment. This apical cellderived fluid is modified after basal supplementation with oestradiol, progesterone and testosterone at physiological and pathophysiological concentrations. Furthermore, using a parallel culture system, we have correlated the expression of bovine oviduct epithelial cell (BOEC) solute carrier genes, with the flux of amino acids in ivDOF after hormonal supplementation.

\section{Materials and methods}

Unless stated otherwise, all reagents were sourced from Sigma-Aldrich.

\section{Bovine oviduct epithelial cell harvest}

Primarily stage II (mid-luteal phase) abattoir-derived bovine reproductive tracts (Ireland et al. 1980) were transported to the laboratory at room temperature in Hank's buffered salt solution (HBSS) (without $\mathrm{CaCl}_{2}$ and $\mathrm{MgCl}_{2}$ ) (Invitrogen), $10 \mathrm{mM}$ HEPES and $1 \mu \mathrm{M}$ Aprotinin - although tracts were not staged for experimentation. Tracts reached the laboratory within $90 \mathrm{~min}$ of slaughter. Cells from isthmus to infundibulum were harvested similarly to Dickens and coworkers (1993) and in accordance with the UK Animal and Plant Health Agency (APHA) regulations.

Bovine oviduct epithelial cells (BOECs) and bovine oviduct fibroblast cells (BOFCs) were subsequently isolated based on their differential adhesion times - cells were initially seeded together in T75 flasks (Sarstedt) and after $18 \mathrm{~h}$ of culture, un-adhered BOECs were removed (Cronin et al. 2012) and re-cultured. Culture medium consisted of 1:1 DMEM and F12, supplemented with $265 \mathrm{U} / \mathrm{mL}$ Pen-Strep, $20 \mu \mathrm{g} / \mathrm{mL}$ amphotericin B, $2 \mathrm{mM}$ L-glutamine, 2.5\% v/v NCS, 2.5\% v/v FBS and 0.75\% $w / v$ BSA.

\section{Bovine oviduct epithelial cell Transwell culture}

BOECs were seeded directly onto the apical surface of $24 \mathrm{~mm}$ Corning Transwell $0.4 \mu \mathrm{m}$ pore cell culture inserts coated with $10 \mu \mathrm{g} / \mathrm{mL}$ laminin at a density of $10^{6} \mathrm{cells} / \mathrm{mL} /$ insert. BOECs were subsequently maintained between apical and basal culture medium-filled chambers, at $39^{\circ} \mathrm{C}$ in $5 \% \mathrm{CO}_{2}, 95 \%$ air. Apical and basal media were replaced every $48 \mathrm{~h}$.

\section{Transepithelial electrochemical resistance (TEER)}

BOEC confluence was determined by transepithelial electrochemical resistance (TEER) measured using an Evom voltmeter fitted with handheld chopstick electrodes (World Precision Instruments). From cell seeding to reaching full confluence, TEER rose from $250 \Omega / \mathrm{cm}^{2}$ to $\sim 800 \Omega / \mathrm{cm}^{2}$ in the course of $\sim 10$ days. In addition to assessing monolayer confluence before experimentation, TEER was also used as a measure of post-treatment cellular integrity. Unless used as a dependent independent variable, data from BOECs whose TEER fell below $700 \Omega / \mathrm{cm}^{2}$ were excluded from analysis (Simintiras et al. 2012).

\section{In vitro-derived oviduct fluid (ivDOF)}

Once confluent, BOECs were cultured in an apical-basal air-liquid interface (Levanon et al. 2010)—the basal medium comprised $2 \mathrm{~mL}$ of culture medium, whereas the apical compartment comprised moist air in $5 \% \mathrm{CO}_{2}$. After $24 \mathrm{~h}$, a thin film of fluid formed in the apical chamber-termed in vitro-derived oviduct fluid (ivDOF) (Fig. 1A).

\section{Dual culture}

Bovine oviduct fibroblast cells were harvested by trypsinization from tissue culture flasks after 5 days in culture. $1 \times 10^{6}$ fibroblast cells were added to the basal surfaces of Transwell semi-permeable supports (Fig. 1B). Fibroblasts were maintained in this manner for approximately 5 days at which point Transwell inserts were reorientated and BOECs were introduced to the apical surfaces.

\section{Hormonal supplementation}

Hormone stocks were prepared in ethanol before supplementation to the basal Transwell chamber. Singular steroid hormone concentrations were based on peripheral plasma levels in the bovine throughout the oestrous cycle as previously reported (Kanchev et al. 1976). Combinatorial stocks to determine the effects of a physiologically relevant range of hormone concentrations on the in vitro model were similarly prepared to represent a minimum, mean and maximum pathophysiological endocrine profile (Kanchev 

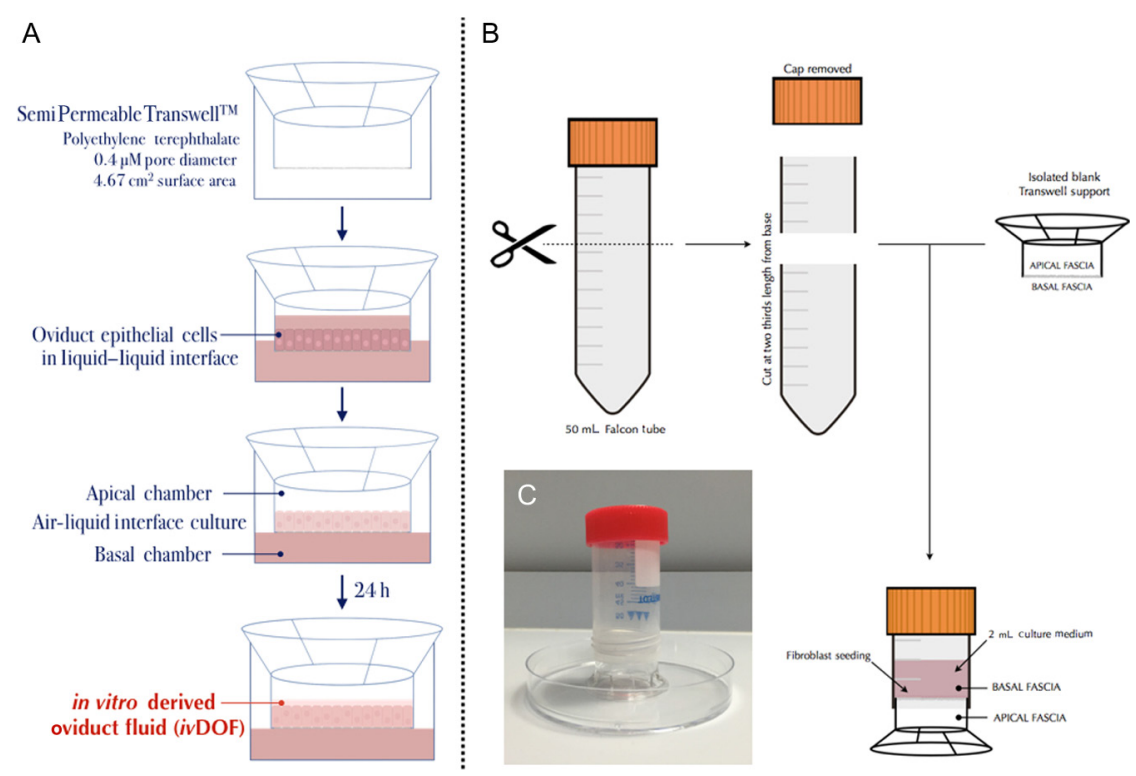

Figure 1 (A) Schematic representation of the culture system for in vitro-derived oviduct fluid (ivDOF) production. The basal chamber represents the bloodstream whilst the apical represents the oviduct lumen. (B) The technical method and apparatus innovated for seeding fibroblasts to the basal surface of Transwell membranes for establishing dual culture. Large Falcon tubes were cut two-thirds from the base and the caps were removed. The top end of the Falcon tube was manually fastened over the inverted Transwell support, whereas the cap was placed over the severed end of the tube. This scaffold could then support cell proliferation on the basal surface of the semi-permeable membrane. et al. 1976, Pastor et al. 1998, Balen 2004, Di Sarra et al. 2013, O'Reilly et al. 2014). The maximum solvent (ethanol) contribution was $<1 \%(\mathrm{v} / \mathrm{v})$ similar to Bromberg and Klibanov (1995) and showed no effect throughout (Table 1).

\section{Fluorescence-activated cell sorting (FACS)}

BOECs and BOFCs were identified based on positive staining for cytokeratin-18 (CK18) and vimentin primary antibodies (Abcam) respectively (Rottmayer et al. 2006, Goodpaster et al. 2008). Samples were analysed on FACSCalibur flow cytometer (Becton Dickinson, Oxford, UK) running CELLQuest software and $>10,000$ events were counted, similarly to Vince and coworkers (2011).

\section{Haematoxylin and eosin staining}

Confluent BOECs cultured on Transwell inserts were manually isolated using a blade. The supports were rinsed three times in pre-equilibrated PBS before 5-min incubation at room temperature in $100 \%$ haematoxylin. Cells were then rinsed three times in $18.2 \mathrm{milliQ}$ water and incubated for $5 \mathrm{~min}$ with $1 \%$ eosin. Following further washes, cells were supplemented with Hydromount (National Diagnostics, Atlanta, GA, USA), placed onto microscope slides and imaged on a Zeiss ApoTome
2 Observer Z1 microscope with a $\times 20$ objective lens and an Axiom 506 mono imager coupled with ZEN imaging software.

\section{Transmission electron microscopy (TEM)}

BOECs fixed in $2.5 \%$ glutaraldehyde in $0.1 \mathrm{M}$ sodium cacodylate buffer, post-fixed in $1 \%$ osmium tetroxide in the same buffer, were stained en bloc in $1 \%$ uranyl acetate (aq) then serially dehydrated in ethanol before being embedded in Epon-Araldite resin. (All chemicals are from Agar Scientific, Stansted, Essex.) Subsequently, $50 \mathrm{~nm}$ sections were cut using a diamond knife on a Leica UC6 Ultramicrotome and collected on carbon-coated copper grids (EM Resolutions, Saffron Walden, Essex, UK). Images were obtained using an Ultrascan 4000 digital camera (Gatan Inc, Pleasanton, CA, USA) attached to a Jeol 2011 Transmission Electron Microscope (Jeol UK Ltd, Welwyn Garden City, Hertfordshire, UK) running at $120 \mathrm{kV}$.

\section{Generation of anti-oviduct-specific glycoprotein (OVGP1) antibodies}

The peptide KMTVTPDGRAETLERRL corresponding to amino acids 521-537 of bovine OVGP1 (UniProtKB Q28042) was synthesised with a 433A Peptide Synthesizer (Applied Biosystems) using Fmoc chemistry (FastMoc $\Omega$

Table 1 Concentration of hormones added to bovine oviduct epithelial cells as different treatments.

\begin{tabular}{lccc}
\hline & $\mathbf{1 7 \beta}$-Oestradiol (E2) & Progesterone (P4) & Testosterone (T) \\
\hline Native (N) & $0 \mathrm{pM}$ & $0 \mathrm{pM}$ & $0 \mathrm{pM}$ \\
17ß-Oestradiol (E2) & $29.37 \mathrm{pM}$ & $0 \mathrm{pM}$ & $0 \mathrm{pM}$ \\
Progesterone (P4) & $0 \mathrm{pM}$ & $6.36 \mathrm{nM}$ & $0 \mathrm{pM}$ \\
Testosterone (T) & $0 \mathrm{pM}$ & $0 \mathrm{pM}$ & $62.77 \mathrm{pM}$ \\
Hypoandrogenic (HYPO) & $29.37 \mathrm{pM}$ & $6.36 \mathrm{nM}$ & $2.43 \mathrm{pM}$ \\
Physiological (PHYS) & $29.37 \mathrm{pM}$ & $6.36 \mathrm{nM}$ & $208 \mathrm{pM}$ \\
Hyperandrogenic (HYPER) & $19.46 \mathrm{pM}$ & $6.36 \mathrm{nM}$ & $6.27 \mathrm{nM}$ \\
\hline
\end{tabular}


Table 2 List of the bovine-specific exon spanning primers used.

\begin{tabular}{|c|c|c|c|c|}
\hline Gene & Direction & Sequence & $\boldsymbol{T}_{\mathrm{m}}\left({ }^{\circ} \mathrm{C}\right)$ & GC (\%) \\
\hline \multirow[t]{2}{*}{$A C T B$} & Forward $\left(3^{\prime}\right.$ to $\left.5^{\prime}\right)$ & TTCAACACСССТGССАТG & 59.64 & 56 \\
\hline & Reverse $\left(5^{\prime}\right.$ to $\left.3^{\prime}\right)$ & TCACCGGAGTCCATCACGAT & 59.73 & 55 \\
\hline \multirow[t]{2}{*}{ OVGP1* } & Forward ( $3^{\prime}$ to $\left.5^{\prime}\right)$ & СTGAGСТССАТССССАСТTG & 57.20 & 60 \\
\hline & Reverse $\left(5^{\prime}\right.$ to $\left.3^{\prime}\right)$ & GTTGCTCATCGAGGCAAAGG & 57.10 & 55 \\
\hline \multirow[t]{2}{*}{$E S R 1^{*}$} & Forward ( $3^{\prime}$ to $\left.5^{\prime}\right)$ & AGGGAAGCTCСТАTTTGСТСC & 57.00 & 52 \\
\hline & Reverse $\left(5^{\prime}\right.$ to $\left.3^{\prime}\right)$ & CGGTGGATGTGGTCCTTCTCT & 57.50 & 57 \\
\hline \multirow[t]{2}{*}{$S L C 1 A 1^{+}$} & Forward ( $3^{\prime}$ to $\left.5^{\prime}\right)$ & CACCGTCCTGAGTGGGCTTGC & 61.30 & 67 \\
\hline & Reverse $\left(5^{\prime}\right.$ to $\left.3^{\prime}\right)$ & CAGAAGAGCCTGGGCCATTCCC & 61.30 & 64 \\
\hline \multirow[t]{2}{*}{$S L C 38 A 2^{\dagger}$} & Forward ( $3^{\prime}$ to $\left.5^{\prime}\right)$ & GAACCCAGACCACCAAGGCAG & 58.10 & 62 \\
\hline & Reverse $\left(5^{\prime}\right.$ to $\left.3^{\prime}\right)$ & GTTGGGCAGCGGGAGGAATCG & 61.80 & 67 \\
\hline \multirow[t]{2}{*}{$S L C 38 A 5^{\dagger}$} & Forward $\left(3^{\prime}\right.$ to $\left.5^{\prime}\right)$ & TGGCСАTСТСGTСТGСТGAGGG & 63.20 & 64 \\
\hline & Reverse $\left(5^{\prime}\right.$ to $\left.3^{\prime}\right)$ & GСТССТGСТССАСАGСАTTCСС & 62.00 & 64 \\
\hline \multirow[t]{2}{*}{ SLC $38 A 7^{+}$} & Forward ( $3^{\prime}$ to $\left.5^{\prime}\right)$ & CGGCAGCCCGAGGTGAAGAC & 61.60 & 70 \\
\hline & Reverse $\left(5^{\prime}\right.$ to $\left.3^{\prime}\right)$ & GCCGCAGATACCTGTGCCCAT & 60.90 & 62 \\
\hline \multirow[t]{2}{*}{ SLC6A $14^{\dagger}$} & Forward ( $3^{\prime}$ to $\left.5^{\prime}\right)$ & TCGAGGGGCAACTCTGGAAGGT & 60.80 & 59 \\
\hline & Reverse $\left(5^{\prime}\right.$ to $\left.3^{\prime}\right)$ & GGCAGCATCTTTCCAАACСТCAGCA & 62.90 & 52 \\
\hline \multirow[t]{2}{*}{ ZO1 } & Forward ( $3^{\prime}$ to $\left.5^{\prime}\right)$ & СТСТTССТGСТTGАССТССС & 56.80 & 60 \\
\hline & Reverse $\left(5^{\prime}\right.$ to $\left.3^{\prime}\right)$ & TCCATAGGGAGATTCCTTCTCA & 55.20 & 45 \\
\hline
\end{tabular}

Those marked * were taken from Ulbrich et al. (2003), whereas primers marked ${ }^{\dagger}$ from Forde et al. (2014).

previous peak method, as suggested by the manufacturer) and TentaGel S RAM (RAPP Polymere, Tübingen, Germany) resin. To further increase immunogenicity, a proprietary peptide carrier was C-terminally coupled. Peptide cleavage and deprotection were performed by incubation in $92.5 \%$ trifluoroacetic acid, 5\% triisopropylsilane and 2.5\% water for $1.5 \mathrm{~h}$. The peptide was precipitated and washed with cool tert-butyl methyl ether. Peptides were further purified using reversed-phase chromatography, and the correctness of the peptide was confirmed using matrix-assisted laser desorption ionisation-time-of-flight mass spectrometry (4800 series; Applied Biosystems). Murine anti-OVGP1 sera were generated by immunisation of female BALB/C mice in intervals of 3 week with $100 \mu \mathrm{g}$ peptide applied subcutaneously. For the first injection, complete Freund's adjuvant and for the following three injections, incomplete Freund's adjuvant was used. Bleeding was performed 10 days after the fourth injection.

\section{Western blotting}

OVGP1 from both abattoir-derived oviduct fluid and ivDOF was qualitatively identified by sodium dodecyl sulphate polyacrylamide gel electrophoresis (SDS-PAGE). Proteins were separated by $10-18 \%$ gradient SDS-PAGE and transferred to polyvinylidene fluoride (PVDF) membranes. PVDF membranes were blocked for $24 \mathrm{~h}$ with $10 \%$ milk dissolved in Tris-buffered saline Tween $(0.1 \%)$, and then incubated at $4{ }^{\circ} \mathrm{C}$ with the custom mouse anti-OVGP1 primary antibody described previously $(1: 1000)$ for $24 \mathrm{~h}$,
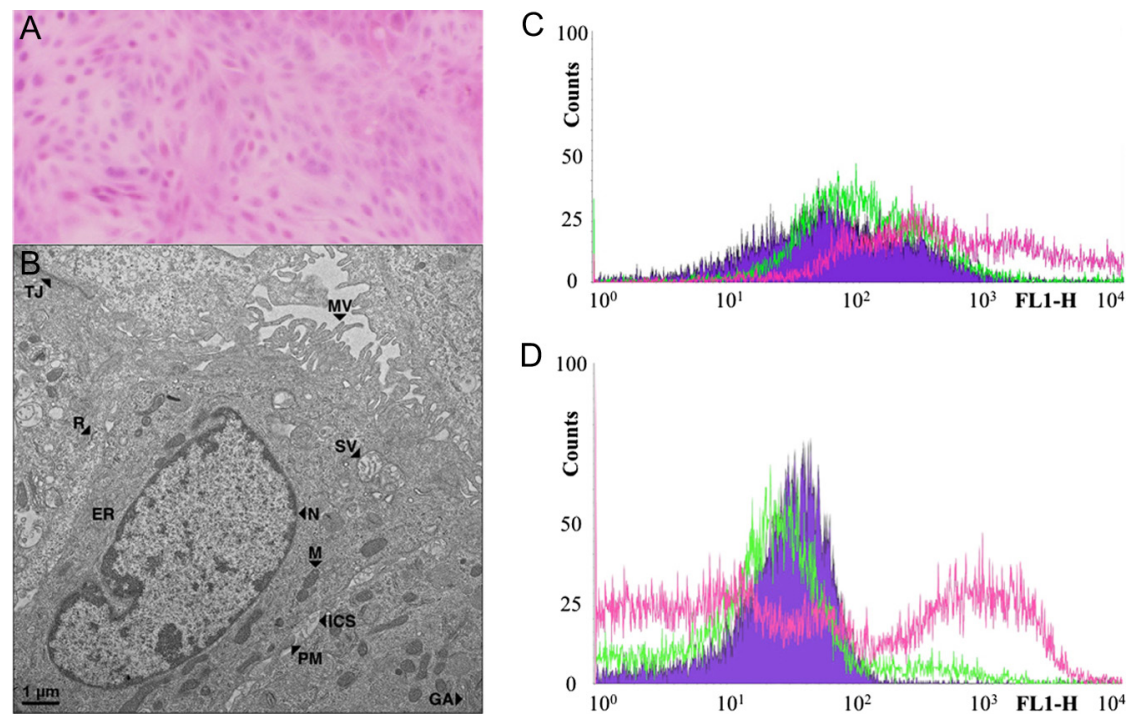

D

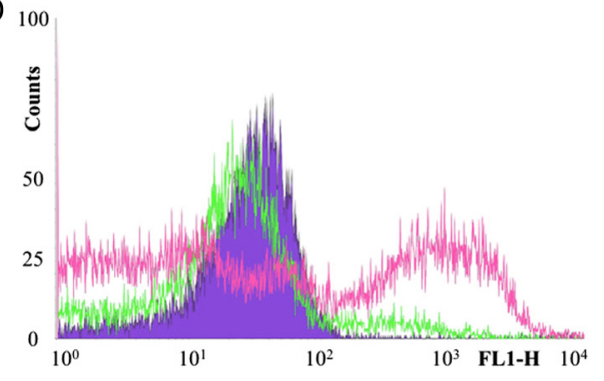

Figure 2 (A) Haematoxylin- and eosin-stained bovine oviduct epithelial cells cultured to confluence on Transwell membranes and imaged at $\times 20$ magnification. (B) Transmission electron microscopy image of bovine oviduct epithelia showing the endoplasmic reticulum (ER), Golgi apparatus (GA), intracellular space (ICS), mitochondria (M), microvilli (MV), nucleus $(\mathrm{N})$, plasma membrane $(\mathrm{PM})$, ribosomes (R), a secretory vesicle (SV) and a tight junction (TJ). (C) FACS analysis of cultured BOEC purity showing mouse IgG1-negative control (background noise), anti-Vimentin $1^{\circ}$ antibody (BOFC population), and anti-Cytokeratin $181^{\circ}$ antibody (BOEC population); all in combination with the Alexafluor $488 \mathrm{~nm} 2^{\circ}$ antibody showing in excess of $95 \%$ epithelial purity (representative of $n=2$ ) at a fluorescence intensity (FLH-1) between 103 and 104. (D) FACS analysis of cultured BOFCs showing mouse IgG1-negative control (background noise), anti-cytokeratin $181^{\circ}$ antibody (BOEC population) and anti-vimentin $1^{\circ}$ antibody (BOFC population) in excess of $99 \%$ stromal purity $(n=1)$. 

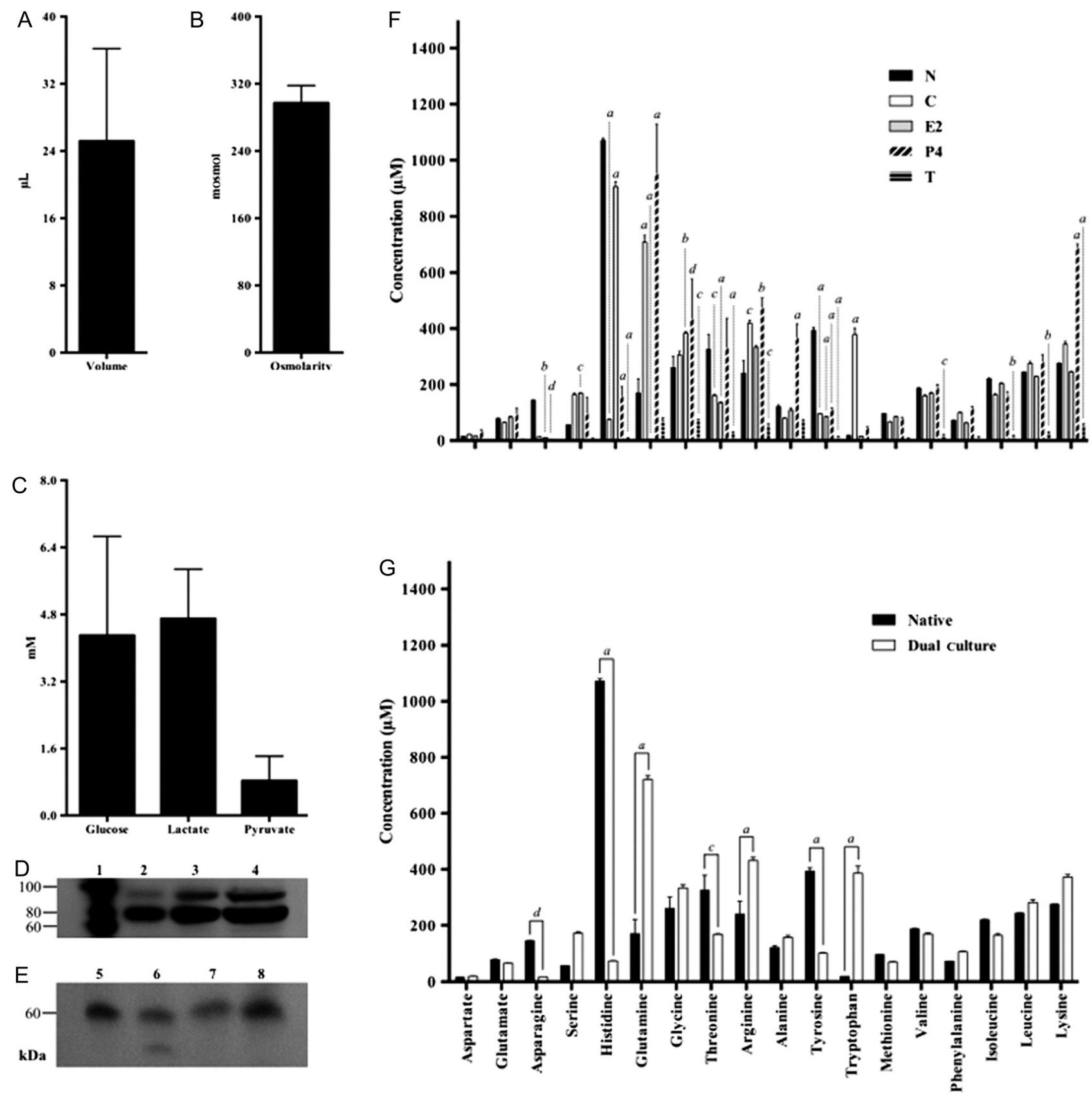

Figure 3 (A) The volume ( $n=6 \pm$ S.D.), (B) osmolarity $(n=3 \pm$ S.D.) and (C) carbohydrate content $(n=3 \pm$ S.D.) of $i v$ DOF obtained from native (untreated) epithelia. (D and E) Western (protein immuno) blots for OVGP1 from (D) in vivo-derived oviduct fluid and cell lysates ( $n=1$ ) and (E) native ivDOF (representative of $n=4$ ). Lane 1 was loaded with a staggered $200 \mathrm{kDa}$ HRP-linked biotinylated protein ladder. Lane 2 with $10 \mathrm{mM}(16.5 \mu \mathrm{L})$ total protein, lane 3 with $20 \mathrm{mM}(33.3 \mu \mathrm{L})$ and lane 4 with $40 \mathrm{mM}(66.7 \mu \mathrm{L})$. Lanes 5-8 were loaded with $40 \mu \mathrm{L}$ (arbitrary concentrations) of native ivDOF. (F) The amino acid composition of $i v D O F$ accumulated apically from native (N) BOECs $(n=12 \pm$ S.D.) vs culture medium (C) supplied basally ( $n=3 \pm$ S.D.) vs ivDOF derived from BOECs basally supplemented with $29.37 \mathrm{pM} 17 \beta$-oestradiol (E2; $n=6 \pm$ s.D.) vs $i v$ DOF from BOECs treated with $6.36 \mathrm{nM}$ progesterone (P4; $n=4 \pm$ s.D.) vs $i v D O F$ from BOECs basally supplemented with $62.77 \mathrm{pM}$ testosterone (T; $n=3 \pm$ s.D.). (G) The amino acid profile of native $i v D O F(n=12 \pm$ s.D.) vs $i v D O F$ from BOECs cultured with BOFCs basally adjacent in the dual culture arrangement $(n=4 \pm$ S.D.). All $i v D O F$ accumulated over $24 \mathrm{~h}$ and $a=P \leq 0.0001, b=P \leq 0.001, \mathrm{c}=P \leq 0.01$ and $d=P \leq 0.05$.

washed and subsequently incubated with an anti-mouse horseradish peroxidase (HRP) linked antibody $(1: 10,000)$ (Cell Signaling Technologies) for $1 \mathrm{~h}$ at room temperature. Bands were visualised by enhanced chemiluminescent $(E C L)$ detection.

\section{Osmolarity and fluorometric assays}

Osmolarity was measured using an Osmomat 030 Osmometer (Gonotec GmbH, Berlin, Germany). Glucose, lactate and pyruvate were quantified indirectly using enzyme-linked fluorometric assays as described in Leese (1983), Leese \& 

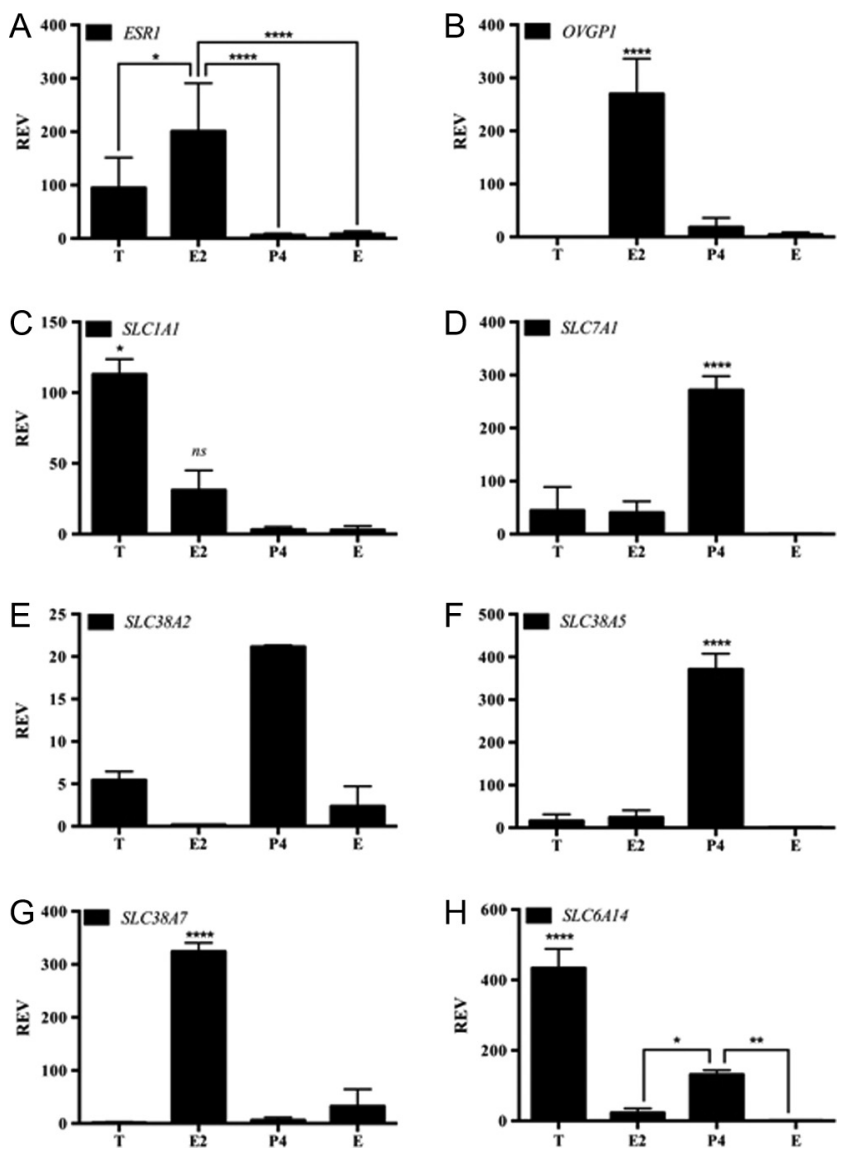

Figure 4 Gene expression profiles of (A) ESR1, (B) OVGP1, (C) SLC1A1, (D) SLC7A1, (E) SLC38A2, (F) SLC38A5, (G) SLC38A7 and $(\mathrm{H})$ SLC6A 14 as determined by qRT-PCR $(n=3 \pm$ s.E.M.). BOECs were subjected to $62.77 \mathrm{pM}$ testosterone (T), $29.37 \mathrm{pM} 17 \beta$-oestradiol (E2), $6.36 \mathrm{nM}$ progesterone (P4) and $0.45 \%(\mathrm{v} / \mathrm{v})$ ethanol $(\mathrm{E})$ as vehicle control - all for $24 \mathrm{~h}$. Data were normalised to ACTB whilst the impact of treatment on gene expression was calculated relative to native BOECs. ${ }^{* * * *} P \leq 0.0001,{ }^{* * *} P \leq 0.001,{ }^{* *} P \leq 0.01$ and $* P \leq 0.05$.

Barton (1984), Gardner \& Leese $(1988,1990)$ and Guerif and coworkers (2013).

\section{High-performance liquid chromatography}

High-performance liquid chromatography (HPLC) was used to measure 18 amino acids as described previously (Humpherson et al. 2005).

\section{Quantitative real-time polymerase chain reaction ( $q R T-P C R)$}

At confluence, BOECs from T25 flasks were subjected to hormonal supplementation (Table 1) for $24 \mathrm{~h}$ before isolation using trypsin. BOECs were washed four times by centrifugation at $1000 \mathrm{~g}$ for $5 \mathrm{~min}$ at $4{ }^{\circ} \mathrm{C}$ and resuspension in pre-chilled $1 \mathrm{~mL}$ phenol red-free HBSS. Total RNA was extracted using TRIzol reagent and chloroform (Chomczynski \& Sacchi 1987). Global cDNA was synthesised by reverse transcription using the High Capacity cDNA Reverse Transcription Kit (Fisher Scientific) in accordance to manufacturer instructions. The concentration $(n g / \mu \mathrm{L})$ and purity (A260/A280) of cDNA generated were determined using a NanoDrop spectrophotometer. All cDNAs were diluted to $1 \mu \mathrm{g} / \mathrm{mL}$. Three technical PCR replicates were prepared per sample in optical 96-well plates and sealed before being loaded onto a Step-one Real-Time PCR machine (Applied Biosystems) for qPCR. The bovine-specific exon spanning primers used are provided in Table 2. To ensure correct product length, melt curves were performed (Giglio et al. 2003), whereas $\Delta \Delta$ Ct method (Livak \& Schmittgen 2001) was used to determine relative expression.

\section{Experimental design}

Retrieved bovine oviduct epithelia were pooled, typically yielding sufficient viable cells to seed 6 Transwell inserts. The standard experimental design was to assign 3 Transwell membranes for treatment with the dependent experimental variable and the remaining 3 as negative controls. The ivDOF obtained from each group was pooled for subsequent analysis. This was defined as a single biological replicate $(n=1)$. Unless otherwise stated, $n=3$ indicates data from three independent abattoir collections and ivDOF isolations.

In this study, in vitro-derived oviduct fluid (ivDOF; Fig. 1A) from untreated (native) bovine oviduct epithelial cells was analysed and compared with previously reported in vivo observations. The composition of ivDOF after singular cellular hormonal supplementation was analysed, and the influence of dual culture was also examined. These data are contrasted against native ivDOF. This system was subsequently expanded upon to investigate the impact of physiological vs pathophysiological endocrine stimulation on fluid composition and cellular physiology. Cell culture flasks were seeded in parallel for gene expression studies to complement ivDOF findings.

\section{Statistical analyses}

Statistical analyses were performed using Prism GraphPad 6 software for Apple Macintosh. All statistical analysis were two way analysis of variance (ANOVA) followed by a Holm-Sidak non-parametric post hoc analysis.

\section{Results}

\section{BOEC and BOFC isolation}

Figure 2A and B confirm the epithelial nature of cells in culture in our model. Additionally, over 95\% of cells were positive for CK18, (Fig. 2C) and over 99\% of the BOFC population stained positive for vimentin (Fig. 2D).

\section{ivDOF characterisation}

The volume of ivDOF from untreated BOECS after a 24-h period of culture was $25.2 \pm 4.5 \mu \mathrm{L}$ (Fig. 3A) and the mean osmolarity was $297 \pm 12$ mosmol (Fig. 3B). Untreated ivDOF contained $4.30 \pm 1.18 \mathrm{mM}$ glucose, $4.70 \pm 0.68 \mathrm{mM}$ lactate and $0.83 \pm 0.34 \mathrm{mM}$ pyruvate (Fig. 3C). Qualitative western blots for OVGP1 were performed on oviduct fluid derived from fresh abattoir tissue (Fig. 3D) and compared with blots given by ivDOF 

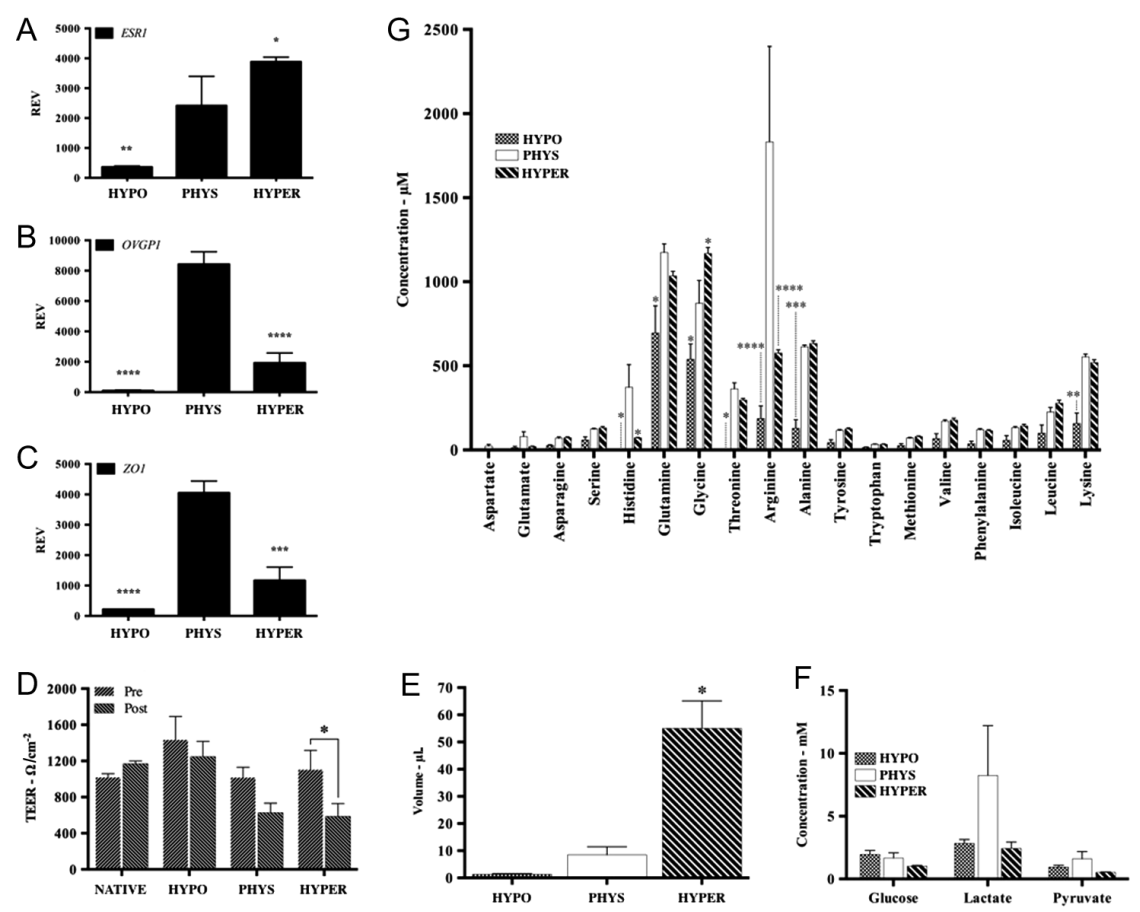

Figure 5 The effects of hypoandrogenic
(HYPO), physiological (PHYS) and
hyperandrogenic (HYPER) like endocrine
supplementation on (A) ESR 1 , (B) OVGP1 and
(C) ZO1 gene expression ( $n=3 \pm$ S.E.M.). (D)
TEER values from BOECs before and after
HYPO, PHYS and HYER exposure in addition
to native ( $n=3 \pm$ s.D.). One statistically
significant difference was determined by
paired $t$-test $(P=0.0214)$. (E) Volumes of $i v D O F$
from HYPO-, PHYS- and HYER-treated BOECs
( $n=3 \pm$ s.D.). (F) The carbohydrate composition
of $i v D O F$ from BOECs subjected to HYPO,
PHYS and HYER exposure ( $n=3 \pm$ S.D.). (G) The
amino acid content of $i v D O F$ obtained from
HYPO-, PHYS- and HYPER-treated cells
$(n=3 \pm$ S.D.). All treatment durations were $24 \mathrm{~h}$.
$* * * * P \leq 0.0001, * * * P \leq 0.001, * * P \leq 0.01$ and
$* P \leq 0.05$.

(Fig. 3E). These figures confirm OVGP1 presence in both oviduct fluids. However, OVGP1 collected from abattoirderived in vivo oviduct fluid showed two prominent bands at $80 \mathrm{kDa}$ and $90 \mathrm{kDa}$, whereas OVGP1 identified in ivDOF was present at $60 \mathrm{kDa}$.

Figure $3 \mathrm{~F}$ shows that the amino acid composition of $i v \mathrm{DOF}$ from untreated BOECs was distinct from that in the medium provided basally (C) with respect to 6/18 amino acids measured. When E2 was added to the basal compartment (Table 1), asparagine, histidine, glutamine, threonine and tyrosine secretion were decreased, whereas the apical accumulation of serine and glycine were elevated compared with native ivDOF (Fig. 3F). Similarly, the addition of P4 (Table 1) increased the apical flux of glutamine, glycine, arginine, alanine and lysine, whilst decreasing histidine and tyrosine secretion (Fig. 3F). Interestingly, treatment with $\mathrm{T}$ (Table 1) significantly decreased the accumulation of 10 amino acids in ivDOF relative to native fluid (Fig. 3F). Figure $3 \mathrm{G}$ shows that culturing BOECs in a dual culture configuration with basally adjacent BOFCs altered the secretion of 7/18 amino acids: asparagine, histidine, threonine and tyrosine movement decreased, whereas glutamine, arginine and tryptophan flux increased.

\section{BOEC gene expression}

OVGP1 and ESR 1 were expressed in flask-cultured cells after harvest and increased after $24 \mathrm{~h}$ of E2 exposure (Fig. 4). In addition, a panel of solute carrier genes was analysed (Table 2). In brief, SLC1A1 and SLC6A14 were upregulated in response to T, $S L C 38 A 7$ expression increased after E2 exposure and SLC7A1 and SLC38A5 expression was elevated after P4 supplementation. The ethanol vehicle control showed no significant impact on gene expression.

\section{Impact of pathophysiological endocrine supplementation}

To further explore the impact of endocrine action on oviduct epithelial cell secretions and to test the capacity of the model for investigating disease, one physiological, and two pathophysiological ranges of hormones were added to the basal compartment (Table 1); the latter represented hypoandrogenism and hyperandrogenism. Figure 5 panels A, B, C show that hyperandrogenism (HYPER) increased the expression of ESR1 in flask-cultured BOECs whilst reducing OVGP1 and ZO1 expression, whereas hypoandrogenism (HYPO) decreased the relative expression of all the genes investigated relative to physiological (PHYS). Hyperandrogenism also reduced BOEC TEER after $24 \mathrm{~h}$ (Fig. 5D) and caused an increase in the volume of ivDOF produced (Fig. 5E). Figure 5F shows that hypo and hyper treatments had no significant impact on the carbohydrate composition of ivDOF. Lastly hypoandrogenism reduced histidine, glutamine, glycine, threonine, arginine, alanine and lysine secretion, whereas hyperandrogenism reduced histidine and arginine but elevated the apical accumulation of glycine (Fig. 5G).

\section{Discussion}

We present a novel application for an existing bovine oviduct epithelial cell preparation, which can be used 
to examine the formation of oviduct fluid in vitro under a variety of conditions. A layer of BOECs were grown on Transwell membranes (Fig. 1A) and were confirmed as confluent by TEER, expressed CK18 (Fig. 2C) and displayed a number of morphological features typical of epithelial cells (Fig. 2A and B). After culture in an airliquid interface for $24 \mathrm{~h}$ after confirmation of confluence, a film of liquid appeared in the apical chamber, which contained OVGP1 protein (Fig. 3E) and was biochemically distinct from the culture medium provided basally (Fig. 3F). We therefore propose that this constitutes an in vitro-derived oviduct fluid (ivDOF). We furthermore present a method for achieving dual culture in vitro (Fig. 1B) and show that incorporating basally adjacent fibroblasts into the model also impacts ivDOF amino acid composition (Fig. 3G). In addition, parallel flaskcultured BOECs expressed the genes ESR 1 and OVGP1 in an E2-responsive manner (Fig. 4). The above were then expanded to test the capacity of this preparation to model pathophysiological endocrine states (Fig. 5).

\section{ivDOF characterisation}

The volume of native ivDOF produced in $24 \mathrm{~h}$ was found to be $25.2 \pm 11.0 \mu \mathrm{L}$ (Fig. 3A); a rate of formation less than the $1.505 \pm 0.291 \mu \mathrm{L} / \mathrm{min}$ previously reported in vivo by Hugentobler and coworkers (2008). The osmolarity of native ivDOF however was $297 \pm 12$ mosmol (Fig. 4B), which correlates well with both what has been observed in vivo $281.0 \pm 2.56$ mosmol (Paisley \& Mickelsen 1979) and the $270-300$ mosmol range of embryo culture media (Sirard \& Coenen 2006). Similarly Hugentobler and coworkers (2008) investigated the glucose, lactate and pyruvate composition of in vivo bovine oviduct. Multiple $t$-tests between these data and Fig. 3C reveal no significant difference between the basic carbohydrate content of ivDOF vs in vivo.

OVGP1 in $i v D O F$ was $\sim 60 \mathrm{kDa}$ (Fig. 4E) suggestive of the de-glycosylated form, in contrast to the $\sim 80-90 \mathrm{kDa}$ product titrated from abattoir-derived oviduct fluid and cell lysates (Fig. 4F) (Boice et al. 1990, Bauersachs et al. 2004). Abe and Abe (1993) and Sendai and coworkers (1994) also reported two OVGP1-specific bands in the murine and bovine at $95 \mathrm{kDa}$ and $\sim 55 \mathrm{kDa}$ respectively. This difference is likely due to a lack of post-translational glycosylation, which would impair electrophoretic mobility by up to $25.3 \mathrm{kDa}$ (Unal et al. 2008). We suspect this is because the culture medium provided is deficient in substrates such as n-acetylglucosamine, required for glycosylation.

The amino acid composition of ivDOF (Fig. 4F) resembled data on cannulated oviducts of anaesthetised heifers (Hugentobler et al. 2007). However, there were some notable differences between the amino acid content of in vivo and in vitro oviduct fluid. Histidine was significantly more abundant in ivDOF than previously recorded levels in the oviduct lumen (Guerin et al. 1995, Hugentobler et al. 2007). One possible explanation for this is that histidine, an imidazole, can act as a pH buffer. The in situ bovine oviduct $\mathrm{pH}$ is 7.6 (Hugentobler et al. 2004), whereas in vitro BOECs were cultured at $\sim \mathrm{pH} \mathrm{7.4.} \mathrm{Although} \mathrm{a} \mathrm{small} \mathrm{difference} \mathrm{in} \mathrm{pH}$, the latter represents a $58.5 \%$ increase in free $\mathrm{H}+$ ions. It could therefore be the case that the native bovine oviduct epithelium secretes histidine to buffer free $\mathrm{H}+$ ions and balance ivDOF $\mathrm{pH}$. Addition of E2 caused histidine in ivDOF to fall, and P4 administration further decreased histidine to $159.3 \mu \mathrm{M}$, closer to the levels observed previously in vivo (Guerin et al. 1995). The addition of $\mathrm{T}$ dramatically reduced histidine secretion from $1071.1 \mu \mathrm{M}$ to $9.7 \mu \mathrm{M}$; thus, histidine transport appears to be subject to T regulation in addition to E2 and P4.

Glutamine was present in native ivDOF at levels very close to those reported in vivo (Guerin et al. 1995, Hugentobler et al. 2007); yet, significantly lower than the concentration in the basal culture medium (Fig. 4F). This is one example that the BOEC epithelium in vitro forms a highly selective barrier. E2 drastically reduced apical glutamine flux, from $170.0 \mu \mathrm{M}$ to $5.3 \mu \mathrm{M}$ whilst $\mathrm{T}$ had no impact and P4 markedly increased glutamine content in ivDOF to $953.5 \mu \mathrm{M}$. This might relate to the importance of glutamine in bovine embryo metabolism (Rieger et al. 1992). Thus, it is unsurprising that P4, the dominant circulatory hormone during pregnancy elevated oviduct glutamine output.

Next, BOECs and BOFCs were simultaneously cultured on either side of the same membrane (Fig. 1B) to provide a closer to physiological environment for modelling the oviduct epithelium (Fazleabas et al. 1997). In this dual culture system, the composition of ivDOF was modified, with increased appearance of 3 amino acids and a decrease in 4 (Fig. 3G). Again histidine and glycine were brought to levels more comparable with in vivo, perhaps suggestive of a compensatory mechanism of oviduct fluid regulation.

Fibroblast-epithelial communication has been extensively studied in the cells of the airways in a variety of species (Woodward et al. 1998, Knight 2001, Parrinello et al. 2005, Noble 2008, Ohshima et al. 2010, Srisuma et al. 2010, Chhetri et al. 2012, Sakai \& Tager 2013, Nishioka et al. 2015), but fibroblast-epithelial interactions have been investigated to a much lesser extent in the oviduct. However, Chen and coworkers (2013b) reported a highly differentiated porcine oviduct epithelial phenotype when cultured in fibroblastconditioned medium.

\section{BOEC gene expression}

To further understand the amino acid transport, the expression of a number of key amino acid transporters were investigated in BOECs cultured in plastic flasks. 
Expression of SLC1A1, the high-affinity I-aspartate excitatory amino acid co-transporter 3 (EAAC3), was increased in response to $\mathrm{T}$ (Fig. 4C) in agreement with Franklin and coworkers (2006). However, SLC1A1 expression did not respond to $\mathrm{P} 4$ in vitro corresponding to earlier reports that $S L C 1 A 1$ expression decreases in the bovine uterine endometrium during the progesteronedependent phase (day 16-20) of ruminant pregnancy (Forde et al. 2014). Notably, as SLC1A1 expression rose in response to a fall in $\mathrm{T}$ aspartate transport (Fig. 3F) suggesting that aspartate flux is not solely a function of SLC1A1 gene expression.

Expression of SLC7A1, the arginine- and lysinespecific cationic amino acid transporter 1 (CAT1) (Bröer 2008) increased in response to P4 supplementation (Fig. 4D), as did the accumulation of arginine and lysine in ivDOF when BOECs were supplemented with P4 (Fig. 3F). P4 similarly upregulated SLC38A5 in vitro (Fig. 4F) corresponding with an increase in alanine and glycine transport as expected (Fig. 3F) and further suggesting that amino acid transport in the oviduct is hormonally regulated.

Using this model, we confirm that BOECs in vitro express hormonally responsive genes, which correlate with previously reported in vivo findings. In most cases, the secretion of amino acids in ivDOF correlated well with transporter expression.

\section{The influence of pathophysiological endocrine supplementation}

As a proof-of-principle sub-study, the efficacy of the aforementioned in vitro oviduct preparation was tested for studying the impact of disease states on the oviduct epithelium and fluid composition. The model was subjected to pathophysiological endocrine stimuli at either end of the androgenic spectrum, in addition to a physiological hormonal balance as a form of control (Table 1).

ESR1 expression (Fig. 5A) in flask-cultured BOECs was surprising as it correlated negatively with E2 supplementation, but positively with $\mathrm{T}$ addition to culture (Table 1). This, however, could be explained by T having a low affinity for the oestrogen receptor in vitro (Rochefort \& Garcia 1976). OVGP1 expression was highest after physiological hormonal supplementation (Fig. 5B) with hypoandrogenic and hyperandrogenic treatment similarly decreasing ZO1 expression relative to physiological (Fig. 5C). To investigate the latter from a functional perspective, using the in vitro oviduct model described, TEER measurements were taken, as epithelial resistance is proportional to ZO1 expression (Sultana et al. 2013). Figure 5D shows that a hyperandrogenic endocrine profile indeed reduced TEER and moreover increased the volume of $i v$ DOF produced (Fig. 5E). It is tempting to speculate that this leaky oviduct phenotype is driven by impaired ER $\alpha$ activity as ZO1 expression is responsive to
E2 (Zeng et al. 2004) and ER activity (Weihua et al. 2003), potentially via a miR-191/425-mediated mechanism (Di Leva et al. 2013). Moreover, Liu and coworkers (1999) reported that T reduced TEER in the Caco-2 cell line.

Figure 5F shows that pathophysiological endocrine conditions did not affect glucose, lactate and pyruvate secretion. Moreover, these carbohydrate outputs did not differ from those from untreated cells (Fig. 3C), despite the known effects of sex hormone-mediated anabolism (Miers \& Barrett 1998) and the associated heightened energetic demands. In contrast, hyperandrogenic treatment had a lesser impact on amino acid flux regulation than hypoandrogenism. A striking observation was the elevation of arginine after physiological hormonal supplementation (Fig. 5G) compared with all other treatments. Given its role in reproduction (Wu et al. 2009, Wang et al. 2015) and early embryo metabolism (Sturmey et al. 2010, Leary 2015), it is unsurprising that this amino acid would appear in ivDOF. Such high appearance could be explained by the fact that arginine can be readily synthesised from glutamate via ornithine (Wu 2010). Glycine was also interesting as it was elevated in ivDOF after hyperandrogenic incubation (Fig. 5G) but reduced after singular T supplementation (Fig. 3F), implying that the regulation of glycine flux is not solely $\mathrm{T}$ dependent.

\section{Conclusions}

We present a method for examining the formation of oviduct fluid under dual culture and a variety of singular, physiological and pathophysiological endocrine conditions within a controlled environment. This development offers the prospect of modelling the influence of the oestrous cycle (in animals) and the menstrual cycle (in women) with the possibility of using the data on the ivDOF generated to optimise embryo culture media.

\section{Declaration of interest}

The authors declare that there is no conflict of interest that could be perceived as prejudicing the impartiality of the research reported.

\section{Funding}

C A S was fully funded by a University of Hull studentship and a Hull York Medical School (HYMS) fellowship.

\section{Acknowledgements}

The authors would like to thank staff at ABP, York, UK, Dr L Madden (FACS), Mrs A Lowry (TEM) (University of Hull, UK), Dr A Aburima, Prof. KM Naseem (WB), and Ms P Sfyri, and Dr A Matsakas (H\&E) (Hull York Medical School, UK), in addition to the University of Hull and the Hull York Medical School for funding CA Simintiras and this work. 


\section{References}

Abe H \& Abe M 1993 Immunological detection of an oviductal glycoprotein in the rat. Journal of Experimental Zoology 266 328-335. (doi:10.1002/ jez.1402660411)

Aguilar J \& Reyley M 2005 The uterine tubal fluid: secretion, composition and biological effects. Animal Reproduction Science 2 91-105.

Balen A 2004 The pathophysiology of polycystic ovary syndrome: trying to understand PCOS and its endocrinology. Clinical Obstetrics and Gynaecology 18 685-706. (doi:10.1016/j.bpobgyn.2004.05.004)

Bauersachs S, Rehfeld S, Ulbrich SE, Mallok S, Prelle K, Wenigerkind H \& Wolf E 2004 Monitoring gene expression changes in bovine oviduct epithelial cells during the oestrous cycle. Journal of Molecular Endocrinology 32 449-466. (doi:10.1677/jme.0.0320449)

Boice ML, Geisert RD, Blair RM \& Verhage HG 1990 Identification and characterization of bovine oviductal glycoproteins synthesized at estrus. Biology of Reproduction 43 457-465. (doi:10.1095/biolreprod43.3.457)

Bröer S 2008 Amino acid transport across mammalian intestinal and renal epithelia. Physiological Reviews 88 249-286. (doi:10.1152/ physrev.00018.2006)

Bromberg LE \& Klibanov AM 1995 Transport of proteins dissolved in organic solvents across biomimetic membranes. PNAS 92 1262-1266. (doi:10.1073/pnas.92.5.1262)

Chen S, Einspanier R \& Schoen J 2013a In vitro mimicking of estrous cycle stages in porcine oviduct epithelium cells: estradiol and progesterone regulate differentiation, gene expression, and cellular function. Biology of Reproduction 89 54, 1-12. (doi:10.1095/biolreprod.113.108829)

Chen S, Einspanier R \& Schoen J 2013b Long-term culture of primary porcine oviduct epithelial cells: validation of a comprehensive in vitro model for reproductive science. Theriogenology 80 862-869. (doi:10.1016/j.theriogenology.2013.07.011)

Chhetri RK, Phillips ZF, Melissa AT \& Oldenburg AL 2012 Longitudinal study of mammary epithelial and fibroblast co-cultures using optical coherence tomography reveals morphological hallmarks of premalignancy. PLOS ONE 7 1-7. (doi:10.1371/journal.pone.0049148)

Chomczynski P \& Sacchi N 1987 Single-step method of RNA isolation by acid guanidinium thiocyanate-phenol-chloroform extraction. Analytical Biochemistry 162 156-159. (doi:10.1016/0003-2697(87)90021-2)

Comer MT, Leese HJ \& Southgate J 1998 Induction of a differentiated ciliated cell phenotype in primary cultures of Fallopian tube epithelium. Human Reproduction 13 3114-3120. (doi:10.1093/humrep/13.11.3114)

Cox CI \& Leese HJ 1995 Effect of purinergic stimulation on intracellular calcium concentration and transepithelial potential difference in cultured bovine oviduct cells. Biology of Reproduction 52 1244-1249. (doi:10.1095/biolreprod52.6.1244)

Coy P, Garcia-Vazquez FA, Visconti PE \& Aviles M 2012 Roles of the oviduct in mammalian fertilisation. Reproduction 144 649-660. (doi:10.1530/REP-12-0279)

Cronin JG, Turner ML, Goetze L, Bryant CE \& Sheldon IM 2012 Toll-like receptor 4 and MYD88-dependent signaling mechanisms of the innate immune system are essential for the response to lipopolysaccharide by epithelial and stromal cells of the bovine endometrium. Biology of Reproduction 86 51, 1-9. (doi:10.1095/biolreprod.111.092718)

Di Leva G, Piovan C, Gasparini P, Ngankeu A, Taccioli C, Briskin D, Cheung DG, Bolon B, Anderlucci L, Alder H et al. 2013 Estrogen mediated-activation of miR-191/425 cluster modulates tumorigenicity of breast cancer cells depending on estrogen receptor status. PLoS Genetics 9 e1003311. (doi:10.1371/journal.pgen.1003311)

Di Sarra D, Tosi F, Bonin C, Fiers T, Kaufman JM, Signori C, Zambotti F, Dall'Alda M, Caruso B, Zanolin ME et al. 2013 Metabolic inflexibility is a feature of women with polycystic ovary syndrome and is associated with both insulin resistance and hyperandrogenism. Journal of Clinical Endocrinology and Metabolism 98 2581-2588. (doi:10.1210/jc.2013-1161)

Dickens CJ, Southgate J \& Leese HJ 1993 Use of primary cultures of rabbit oviduct epithelial cells to study the ionic basis of tubal fluid formation. Journal of Reproduction and Fertility 98 603-610. (doi:10.1530/jrf.0.0980603)

Fazleabas AT, Bell SC, Fleming S, Sun J \& Lessey BA 1997 Distribution of integrins and the extracellular matrix proteins in the baboon endometrium during the menstrual cycle and early pregnancy. Biology of Reproduction 56 348-356. (doi:10.1095/biolreprod56.2.348)

Forde N, Simintiras CA, Sturmey R, Mamo S, Kelly AK, Spencer TE, Bazer FW \& Lonergan P 2014 Amino acids in the uterine luminal fluid reflects the temporal changes in transporter expression in the endometrium and conceptus during early pregnancy in cattle. PLOS ONE 9 e100010. (doi:10.1371/journal.pone.0100010)

Franklin RB, Zou J, Yu Z \& Costello LC 2006 EAAC1 is expressed in rat and human prostate epithelial cells; functions as a high-affinity I-aspartate transporter; and is regulated by prolactin and testosterone. BioMed Central Biochemistry 7 1-8. (doi:10.1186/1471-2091-7-10)

Gardner DK \& Leese HJ 1988 The role of glucose and pyruvate transport in regulating nutrient utilization by preimplantation embryos. Development $104423-429$.

Gardner DK \& Leese HJ 1990 Concentrations of nutrients in mouse oviduct fluid and their effects on embryo development and metabolism in vitro. Journal of Reproduction and Fertility 88 361-368. (doi:10.1530/ jrf.0.0880361)

Giglio S, Monis PT \& Saint CP 2003 Demonstration of preferential binding of SYBR Green I to specific DNA fragments in real-time multiplex PCR. Nucleic Acids Research 15 e136. (doi:10.1093/nar/gng135)

González S, Ibanez E \& Santalo J 2011 Influence of early fate decisions at the two-cell stage on the derivation of mousse embryonic stem cell lines. Stem Cell Research 7 54-65. (doi:10.1016/j.scr.2011.03.005)

Goodpaster T, Legesse-Miller S, Hameed MR, Aisner SC, RandolphHabecker J \& Coller HA 2008 An immunohistochemical method for identifying fibroblasts in formalin-fixed, paraffin-embedded tissue. Journal of Histochemistry and Cytochemistry 56 347-358. (doi:10.1369/ jhc.7A7287.2007)

Gualtieri R, Mollo V, Braun S, Barbato V, Fiorentino I \& Talevi R 2012 Long-term viability and differentiation of bovine oviductal monolayers: bidimensional versus three-dimensional culture. Theriogenology $\mathbf{7 8}$ 1456-1464. (doi:10.1016/j.theriogenology.2012.06.010)

Gualtieri R, Mollo V, Braun S, Barbato V, Fiorentino I \& Talevi R 2013 Bovine oviductal monolayers cultured under three-dimension conditions secrete factors able to release spermatozoa adhering to the tubal reservoir in vitro. Theriogenology 79 429-435. (doi:10.1016/j. theriogenology.2012.10.014)

Guerif F, McKeegan P, Leese HJ \& Sturmey RG 2013 A Simple Approach for COnsumption and RElease (CORE) Analysis of Metabolic Activity in Single Mammalian Embryos. PLoS One 8 e67834. (doi:10.1371/journal. pone.0067834)

Guerin P, Gallois E, Croteau S, Revol N, Maurin F, Guillaud J \& Menezo Y 1995 Techniques de recolte et aminogrammes des liquides tubaire et folliculaire chez les femelles domestiques. Revuede Medecine Veterinaire 146 805-814.

Hackett AJ, Durnford R, Mapletoft RJ \& Marcus GJ 1993 Location and status of embryos in the genital tract of superovulated cows 4 to 6 days after insemination. Theriogenology 40 1147-1153. (doi:10.1016/0093691X(93)90285-D)

Hugentobler S, Morris DG, Kane MT \& Sreenan JM 2004 In situ oviduct and uterine $\mathrm{pH}$ in cattle. Theriogenology 61 1419-1427. (doi:10.1016/j. theriogenology.2003.08.008)

Hugentobler SA, Diskin MG, Leese HJ, Humpherson PG, Watson T, Sreenan JM \& Morris DG 2007 Amino acids in oviduct and uterine fluid and blood plasma during the estrous cycle in the bovine. Molecular Reproduction and Development 74 445-454. (doi:10.1002/mrd.20607)

Hugentobler SA, Humpherson PG, Leese HJ, Sreenan JM \& Morris DG 2008 Energy substrates in bovine oviduct and uterine fluid and blood plasma during the oestrous cycle. Molecular Reproduction and Development 75 496-503. (doi:10.1002/mrd.20760)

Humpherson PG, Leese HJ \& Sturmey RG 2005 Amino acid metabolism of the porcine blastocyst. Theriogenology 64 1852-1866. (doi:10.1016/j. theriogenology.2005.04.019)

Ireland JJ, Murphee RL \& Coulson PB 1980 Accuracy of predicting stages of bovine estrous cycle by gross appearance of the corpus luteum. Journal of Dairy Science 63 155-160. (doi:10.3168/jds.S0022-0302(80)82901-8)

Kanchev LN, Dobson H, Ward WR \& Fitzpatrick RJ 1976 Concentration of steroids in bovine peripheral plasma during the oestrous cycle and the effect of betamethasone treatment. Journal of Reproduction and Fertility 48 341-345. (doi:10.1530/jrf.0.0480341)

Keating N \& Quinlan LR 2008 Effect of basolateral adenosine triphosphate on chloride secretion by bovine oviductal epithelium. Biology of Reproduction 78 1119-1126. (doi:10.1095/biolreprod.107.065508)

Keating N \& Quinlan LR 2012 Small conductance potassium channels drive ATP-activated chloride secretion in the oviduct. American Journal of Physiology Cell Physiology 302 C100-C109. (doi:10.1152/ ajpcell.00503.2010) 
Knight D 2001 Epithelium-fibroblast interactions in response to airway inflammation. Immunology and Cell Biology 79 160-164. (doi:10.1046/ j.1440-1711.2001.00988.x)

Leary C 2015 The effect of maternal overweight and obesity on the viability and metabolism of human oocytes and early embryos. PhD Thesis. Hull York Medical School.

Leese HJ 1983 Studies on the movement of glucose, pyruvate and lactate into the ampulla and isthmus of the rabbit oviduct. Quarterly Journal of Experimental Physiology 68 89-96. (doi:10.1113/expphysiol.1983. sp002705)

Leese HJ \& Barton AM 1984 Pyruvate and glucose uptake preimplantation embryos. Journal of Reproduction and Fertility 72 9-13. (doi:10.1530/ jrf.0.0720009)

Leese HJ, Hugentobler SA, Gray SM, Morris DG, Sturmey RG, Whitear SL \& Sreenan JM 2008 Female reproductive tract fluids: composition, mechanism of formation and potential role in the developmental origins of health and disease. Reproduction, Fertility and Development 20 1-8. (doi:10.1071/RD07153)

Levanon K, Ng V, Piao HY, Zhang Y, Chang MC, Roh MH, Kindelberger DW, Hirsch MS, Crum CP, Marto JA et al. 2010 Primary ex vivo cultures of human fallopian tube epithelium as a model for serous ovarian carcinogenesis. Oncogene 29 1103-1113. (doi:10.1038/onc.2009.402)

Liu DZ, Lecluyse EL \& Thakker DR 1999 Dodecylphosphocholinemediated enhancement of paracellular permeability and cytotoxicity in Caco-2 cell monolayers. Journal of Pharmaceutical Sciences 881161 1168. (doi:10.1021/js990094e)

Livak KJ \& Schmittgen TD 2001 Analysis of relative gene expression data using real-time quantitative PCR and the 2-Delta Delta C(T) Method. Methods 25 402-408. (doi:10.1006/meth.2001.1262)

Miers WR \& Barrett EJ 1998 The role of insulin and other hormones in the regulation of amino acid and protein metabolism in humans. Journal of Basic and Clinical Physiology and Pharmacology 9 235-354. (doi:10.1515/JBCPP.1998.9.2-4.235)

Nishioka M, Venkatesan N, Dessalle K, Mogas A, Kyoh S, Lin TY, Nair P, Baglole CJ, Eidelman DH, Ludwig MS et al. 2015 Fibroblast-epithelial cell interactions drive epithelial-mesenchymal transition differently in cells from normal and COPD patients. Respiratory Research 1672. (doi:10.1186/s12931-015-0232-4)

Noble PW 2008 Epithelial fibroblast triggering and interactions in pulmonary fibrosis. European Respiratory Review 17 123-129. (doi:10.1183/09059180.00010904)

O'Reilly MW, Taylor AE, Crabtree NJ, Hughes BA, Capper F, Crowley RK, Stewart PM, Tomlinson JW \& Arlt W 2014 Hyperandrogenemia predicts metabolic phenotype in polycystic ovary syndrome: the utility of serum androstenedione. Journal of Clinical Endocrinology and Metabolism 99 1027-1036. (doi:10.1210/jc.2013-3399)

Ohshima M, Yamaguchi Y, Matsumoto N, Micke P, Takenouchi Y, Nishida T, Kato M, Komiyama K, Abiko Y, Ito K et al. 2010 TGF- $\beta$ signaling in gingival fibroblast-epithelial interaction. Journal of Dental Research $\mathbf{8 9}$ 1315-1321. (doi:10.1177/0022034510378423)

Paisley LG \& Mickelsen DW 1979 Continuous collection and analysis of bovine oviduct fluid: preliminary results. Theriogenlogy 11 375-384. (doi:10.1016/0093-691X(79)90061-X)

Parrinello S, Coppe JP, Krtolica A \& Campisi J 2005 Stromal-epithelial interactions in aging and cancer: senescent fibroblasts alter epithelial cell differentiation. Journal of Cell Science 118 485-496. (doi:10.1242/ jcs.01635)

Pastor CL, Griffin-Korf ML, Alio JA, Evans WS \& Marshall JC 1998 Polycystic ovary syndrome: evidence for reduced sensitivity of the gonadotropin-releasing hormone pulse generator to inhibition by estradiol and progesterone. Journal of Clinical Endocrinology and Metabolism 83 582-590. (doi:10.1210/jc.83.2.582)

Rieger D, Loskutoff NM \& Betteridge KJ 1992 Developmentally related changes in the metabolism of glucose and glutamine by cattle embryos produced and co-cultured in vitro. Journal of Reproduction and Fertility 95 585-595. (doi:10.1530/jrf.0.0950585)

Rochefort H \& Garcia M 1976 Androgen on the estrogen receptor: I. Binding and in vivo nuclear translocation. Steroids 28 549-560. (doi:10.1016/0039-128X(76)90023-4)

Rottmayer R, Ulbrich SE, Kölle S, Prelle K, Neumueller C, Sinowatz F, Meyer HHD, Wolf E \& Hiendleder S 2006 A bovine oviduct epithelial cell suspension culture system suitable for studying embryo-maternal interactions: morphological and functional characterization. Reproduction 132 637-648. (doi:10.1530/rep.1.01136)

Sakai N \& Tager AM 2013 Fibrosis of two: epithelial cell-fibroblast interactions in pulmonary fibrosis. Biochimica et Biophysica Acta 1832 911-921. (doi:10.1016/j.bbadis.2013.03.001)

Sendai Y, Abe H, Kikuchi M, Satoh T \& Hoshi H 1994 Purification and molecular cloning of bovine oviduct-specific glycoprotein. Biology of Reproduction 50 927-934. (doi:10.1095/biolreprod50.4.927)

Simintiras CA, Courts FL \& Sturmey RG 2012 Genistein transport across the bovine oviduct epithelium. Reproduction, Fertility and Development 25 208-209. (doi:10.1071/RDv25n1Ab123)

Sirard MA \& Coenen K 2006 In vitro maturation and embryo production in cattle. In Methods in Molecular Biology - Nuclear Transfer Protocols: Cell Reprogramming and Transgenesis, vol 348, pp 35-42. Eds PJ Verma \& A Trounson. Totowa, NJ, USA: Humana.

Srisuma S, Bhattacharya S, Simon DM, Solleti SK, Tyagi S, Starcher B \& Mariani TJ 2010 Fibroblast growth factor receptors control epithelialmesenchymal interactions necessary for alveolar elastogenesis. American Journal of Respiratory and Critical Care Medicine 181838 850. (doi:10.1164/rccm.200904-0544OC)

Sturmey RG, Bermejo-Alvarez P, Gutierrez-Adan A, Rizos D, Leese HJ \& Lonergan P 2010 Amino acid metabolism of bovine blastocysts: a biomarker of sex and viability. Molecular Reproduction and Development 77 285-296. (doi:10.1002/mrd.21145)

Sultana R, McBain AJ \& O'Neill CA 2013 Strain-dependent augmentation of tight-junction barrier function in human primary epidermal keratinocytes by lactobacillus and bifidobacterium lysates. Applied and Environmental Microbiology 79 4887-4894. (doi:10.1128/AEM.00982-13)

Ulbrich SE, Kettler A \& Einspanier R 2003 Expression and localization of estrogen receptor alpha, estrogen receptor beta and progesterone receptor in the bovine oviduct in vivo and in vitro. Journal of Steroid Biochemistry and Molecular Biology 84 279-289. (doi:10.1016/S0960-0760(03)00039-6)

Unal ES, Zhao R, Qiu A \& Goldman ID 2008 N-linked glycosylation and its impact on the electrophoretic mobility and function of the human protoncoupled folate transporter (HsPCFT). Biochimica et Biophysica Acta (BBA) - Biomembranes 1778 1407-1414. (doi:10.1016/j.bbamem.2008.03.009)

Vince RV, Midgley AW, Laden G \& Madden LA 2011 The effect of hyperbaric oxygen preconditioning on heat shock protein 72 expression following in vitro stress in human monocytes. Cell Stress and Chaperones 16 339-343. (doi:10.1007/s12192-010-0246-2)

Walter I 1995 Culture of bovine oviduct epithelial cells (BOEC). Anatomical Records 243 347-356. (doi:10.1002/ar.1092430309)

Wang X, Burghardt RC, Romero JJ, Hansen TR, Wu G \& Bazer FW 2015 Functional roles of arginine during the peri-implantation period of pregnancy. III: arginine stimulates proliferation and interferon tau production by ovine trophectoerm cells via nitric oxide and polyamineTSC2-MTOR signalling pathways. Biology of Reproduction 92 1-17. (doi:10.1095/biolreprod.114.125542)

Weihua Z, Andersson S, Cheng G, Simpson ER, Warner M \& Gustafsson JA 2003 Update on estrogen signaling. FEBS Letters 546 17-24. (doi:10.1016/S0014-5793(03)00436-8)

Woodward TL, Sia MA, Blaschuk OW, Turner JD \& Laird DW 1998 Deficient epithelial-fibroblast heterocellular gap junction communication can be overcome by co-culture with an intermediate cell type but not by E-cadherin transgene expression. Journal of Cell Science 111 3529-3539.

Wu G 2010 Functional amino acids in growth, reproduction, and health. Advances in Nutrition $131-37$. (doi:10.3945/an.110.1008)

Wu G, Bazer FW, Davis TA, Kim SW, Li P, Rhoads JM, Scatterfield MC, Smith SB, Spencer TE \& Yin Y 2009 Arginine metabolism and nutrition in growth, health, and disease. Amino Acids 37 153-168. (doi:10.1007/ s00726-008-0210-y)

Zeng R, Li X \& Gorodeski GI 2004 Estrogen abrogates transcervical tight junctional resistance by acceleration of occludin modulation. Journal of Clinical Endocrinology and Metabolism 89 5145-5155. (doi:10.1210/ jc.2004-0823)

Received 5 November 2015

First decision 22 December 2015

Revised manuscript received 20 September 2016

Accepted 13 October 2016 